\title{
Brazilian Semi-Arid Ascomycetes I: New and interesting records of hysteriaceous ascomycetes
}

\author{
Almeida DAC ${ }^{1}$, Gusmão $\mathrm{LFP}^{1}$ and Miller $\mathrm{AN}^{2}$ \\ ${ }^{1}$ Universidade Estadual de Feira de Santana, Av. Transnordestina, S/N - Novo Horizonte, 44036-900. Feira de \\ Santana, BA, Brazil.daviaugusto@gmail.com \\ ${ }^{2}$ Illinois Natural History Survey, University of Illinois, 1816 S. Oak St., Champaign, IL 61820
}

Almeida DAC, Gusmão LFP and Miller AN 2014 - Brazilian Semi-Arid Ascomycetes I: new and interesting records of hysteriaceous ascomycetes. Mycosphere 5(2), 379-391, Doi 10.5943/mycosphere/5/2/11

\begin{abstract}
During an investigation of ascomycetes carried out in one area of Caatinga and three enclaves of the Atlantic Forest in the semi-arid region of Brazil, we found ten interesting species of hysteriaceous ascomycetes. Psiloglonium clavisporum and Rhytidhysteron opuntiae are new records for South America and Anteaglonium abbreviatum, Hysterium angustatum and Hysterobrevium smilacis are new records for Brazil. All species are described, illustrated and discussed.
\end{abstract}

Key words - biodiversity - taxonomy - tropical microfungi

\section{Introduction}

The ascomycetes traditionally referred to as hysteriaceous fungi (Clements 1909) are characterized by navicular, carbonaceous ascomata, known as hysterothecia, that dehisce by a longitudinal slit and contain pseudoparaphyses and bitunicate asci (Boehm et al. 2009b). They are cosmopolitan, usually saprobes or weak parasites occurring on dead leaves, bark, wood, stems or twigs in terrestrial habitats. Due to their similar ascomatal morphology, they were historically classified under the same family, Hysteriaceae (Bisby 1923). Later the species possessing laterally compressed ascomata with an evaginated slit (mytilinidioid forms) were placed in a separate family, Mytilinidiaceae (Barr 1990a). However, phylogenetic studies based on DNA and amino acid sequence data revealed that the hysterothecium evolved several times within Pleosporomycetidae (Boehm et al. 2009a; Boehm et al. 2009b). Although these studies supported the classification of Hysteriaceae and Mytilinidaceae in their own orders, Hysteriales and Mytiliniales, respectively, they also revealed the existence of a distinct lineage possessing dichotomously branched hysterothecia that are laterally anastomosed along their length and occur on a conspicuous subiculum to which the family Gloniaceae incertae sedis was erected (Boehm et al. 2009b). Other genera with hysterothecia such as Farlowiella and Hysterographium were classified as Pleosporomycetidae incertae sedis (Boehm et al. 2009a; Mugambi \& Huhndorf 2009), and the new family Anteagloniaceae was proposed for Anteaglonium in Pleosporales (Hyde et al. 2013).

The diversity of hysteriaceous ascomycetes in Brazil is poorly known. The first record of a hysteriaceous ascomycete for Brazil was Rhytidhysteron rufulum (Spreng.) Speg. (as R. brasiliense 
and $R$. viride) reported by Spegazzini (1881b). Zogg (1962) added one more record, providing a description and illustration of Ostreichnion curtisii (Duby) M.E. Barr (as Glonium curtisii). Later, Batista et al. (1967) reported Hysterographium bonariense Speg., considered doubtful by Zogg (1962), and Rhytidhysteron rufulum (as R. fuscum). Recently, Vitória (2012) reported the occurrence of Gloniopsis praelonga (Schwein.) Underw. \& Earle on a decaying rachis of Elaeis guineensis Jacq. and on a decaying petiole of Mauritia flexuosa L.f. in northeastern Brazil.

The present work is the first of a series of studies regarding the diversity of Dothideomycetes and Sordariomycetes in the Caatinga biome in the semi-arid region of Brazil. The goal of these studies is to contribute to the knowledge about the diversity of ascomycetes in this region of Brazil through the description and illustration of new and interesting taxa.

\section{Materials \& Methods}

\section{Study area and morphological examination}

Samples of dead twigs and decaying wood were collected from March 2011 to May 2013 in the Caatinga biome of the Brazilian semi-arid region in the following four areas: Paraiba State, Mata do Pau-Ferro State Ecological Reserve (658'14”S, 3544'55”W), Ceará State, Ubajara

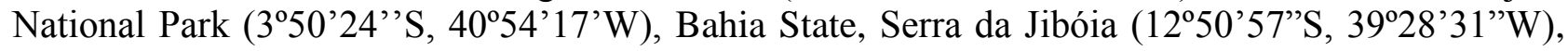

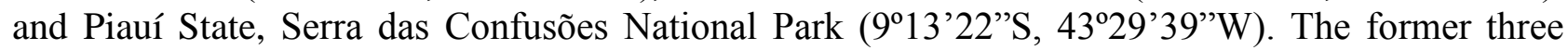
areas are enclaves of Atlantic Forest located on mountain tops, while the fourth is characterized by caatinga vegetation. Ascomata were measured and photographed using a QColor3 Olympus digital camera mounted on a MZ7.5 Leica dissecting microscope. Ascomata were then sectioned with a razor blade and the centrum was placed in a drop of water on a glass slide and covered with a cover slip. Measurements and digital images of the pseudoparaphyses, asci and ascospores were made using a BX51 Olympus microscope equipped with brightfield and Nomarski interference optics and a QColor3 Olympus digital camera. Images were processed using Adobe Photoshop CS6 and ImageJ. Specimens are deposited in the Herbarium of the State University of Feira de Santana (HUEFS).

\section{Results}

\section{Taxonomy}

Anteaglonium abbreviatum (Schwein.) Mugambi \& Huhndorf, Syst. Biodiv. 7(4): 460. 2009.

Figs. 1a-d.

$\equiv$ Hysterium abbreviatum Schwein., Trans. Am. Phil. Soc., New Series 4(2): no. 2094. 1832.

For more synonyms see Index Fungorum (www.indexfungorum.org).

Habitat - Saprobe on twigs or decorticated wood of unidentified plant. Sexual state: Hysterothecia erumpent to superficial, carbonaceous, black, subglobose to oblong, straight, smooth or slightly striate laterally, with a longitudinal slit, sulcus shallow, gregarious, linear or rarely lying at irregular angles, occurring on a black thin crust, tending to darken the substratum, without $\mathrm{KOH}$ extractable pigment, $0.3-1 \times 0.1-0.3 \mathrm{~mm}, 0.1-0.2 \mathrm{~mm}$ high. Pseudoparaphyses aseptate, hyaline, branched above the asci, 1-2 $\mu \mathrm{m}$ wide. Asci bitunicate, cylindrical, short pedicillate, 8-spored, obliquely to irregularly uniseriate, $37-75 \times 4-5 \mu \mathrm{m}$. Ascospores ellipsoid to obovoid, straight, hyaline, smooth, 1-septate, constricted at the septum, guttulate, $4.5-7(-8.5) \times 2.5-4 \mu \mathrm{m}$. Asexual state: Unknown.

Geographical distribution - Argentina, Chinese Taipei, Costa Rica, Ghana, India, New Zealand, Papua New Guinea, Republic of Korea, Sierra Leone, South Africa, Spain, Turkey, United States (GBIF 2013), Chile, Ecuador, Italy, Puerto Rico (Farr et al. 2013), Kenya (Mugambi \& Huhndorf 2009).

Material examined - Brazil, Piauí, Caracol, Serra das Confusões National Park, on decorticated twig of unidentified plant, 28 Mar 2011, D.A.C. Almeida (HUEFS 42833); on 
decorticated wood of unidentified plant, 28 Mar 2011, D.A.C. Almeida (HUEFS 42842); Ceará, Ubajara, Ubajara National Park, on decorticated twig of unidentified plant, 4 May 2012, D.A.C. Almeida (HUEFS 155111, HUEFS 141565); on decorticated wood of unidentified plant, 20 May 2013, D.A.C. Almeida \& A.N. Miller (HUEFS 194240).

Notes - The characteristics of the Brazilian specimens are in agreement with those presented by Lohman (1937), which based his description on the type specimen of A. abbreviatum (as Glonium abbreviatum), Zogg (1962) and Lorenzo \& Messuti (1998). Mugambi \& Huhndorf (2009) reported the production of a $\mathrm{KOH}$ extractable pigment from the ascomata of $A$. abbreviatum, however this characteristic was not reported by the above mentioned authors and not observed in the Brazilian specimens. Although Anteaglonium abbreviatum is widely distributed throughout the world having been found in North, Central and South America, Africa, Asia, Europe and Oceania (Farr et al. 2013; GBIF 2013), this study represents the first record for Brazil.

Gloniella adianti (Kunze) Petr. [as 'adianthi'], Annls. Mycol. 29(1/2): 120. 1931.

Figs. 1e-h $\equiv$ Hysterium adianti Kunze [as 'adianthi'], Flora Jena 13: 371. 1830.

For more synonyms see Index Fungorum (www.indexfungorum.org).

Habitat - Saprobe on decorticated wood of unidentified plant. Sexual state: Hysterothecia superficial, carbonaceous, black, navicular, straight, smooth laterally, with a longitudinal slit that is at first closed, opening slightly at maturity, gregarious, linear, tending to darken the substratum, without $\mathrm{KOH}$ extractable pigment, $0.4-1.5 \mathrm{~mm} \times 0.1-0.3 \mathrm{~mm}, 0.1-0.2 \mathrm{~mm}$ high. Pseudoparaphyses aseptate, hyaline, branched, anastomosed distally, forming a pigmented epithecium above the asci, 1-1.5 $\mu \mathrm{m}$ wide. Asci bitunicate, cylindrical to clavate, short pedicillate, 8-spored, obliquely uniseriate, $70-104 \times 10.5-17 \mu \mathrm{m}$. Ascospores ellipsoid to fusiform, rarely clavate, slightly curved or straight, hyaline, smooth, 3-septate, constricted at the septum, supra-median cell slightly broader than other cells, guttulate, surrounded by a gelatinous sheath, 15-21 $\times 4.5-8 \mu \mathrm{m}$. Asexual state: Unknown.

Geographical distribution - Brazil (GBIF 2013), England, Ireland (Farr et al. 2013), Portugal (Zogg 1962).

Material examined - Brazil, Ceará, Ubajara, Ubajara National Park, on decorticated wood of unidentified plant, 15 Nov 2012, D.A.C. Almeida (HUEFS 192136).

Notes - Gloniella is currently classified in Hysteriaceae (Lumbsch \& Huhndorf 2010). Zogg (1962) accepted six species in his account of the genus with an additional seven species later added (Joshi \& Patwardhan 1971; Sivanesan et al. 1988; Pande \& Rao 1991; Steinke \& Hyde 1997; Checa et al. 2007). Since the size of the ascospores of many species of Gloniella are identical or nearly so, Steinke \& Hyde (1997) and Boehm et al. (2009a) suggested that many species may be conspecific. Two species considered doubtful by Zogg (1962) were recognized by Barr (2009), $G$. abietina Syd and G. lapponica (P. Karst.) Sacc. Recently, Messuti \& Lorenzo (2009) reviewed six type species of Gloniella from Chile and Argentina described by Spegazzini, all of them considered doubtful species by Zogg (1962). As a result, two species were maintained as doubtful, $G$. antarctica Speg. and G. gilliesi Speg., and three species were recognized, G. australis Speg., G. chilensis Speg. and G. multiseptata Speg. Gloniella australis var. minor was considered a synonym of G. australis. Although Messuti \& Lorenzo (2009) did not examine the type of G. araucana Speg., they also maintained it as a doubtful species.

The Brazilian specimen has longer asci and wider ascospores than presented by Zogg (1962) for G. adianti (asci (25)30-40(45) $\mu \mathrm{m}$ long; ascospores 3-5 $\mu \mathrm{m}$ wide). Other differences are the occurrence of the ascomata on a substratum tending to darken and the presence of a sheath in the ascospores of the Brazilian specimen. However, since the morphology and length of the ascospores are identical to those reported by Zogg (1962), we consider the observed differences to be variations within the species and not sufficient to warrant a new taxon. Thus, we prefer to assign our material to G. adianti and expand the concept of this species. Obviously, a review of the genus and its species based on molecular data is necessary to clarify its phylogenetic placement within Dothideomycetes and establish species boundaries within the genus. 
Hysterium angustatum Alb. \& Schwein., Consp. Fungi (Leipzig): 55. 1805.

Figs. 1i-1

For synonyms see Index Fungorum (www.indexfungorum.org).

Habitat - Saprobe on twigs of unidentified plant. Sexual state: Hysterothecia superficial with base immersed, carbonaceous, black, subglobose to elongate, straight or flexuous, smooth laterally, with a longitudinal slit, sulcus shallow, gregarious, lying at irregular angles, without $\mathrm{KOH}$ extractable pigment $0.2-1.4 \times 0.1-0.3 \mathrm{~mm}, 0.1-0.3 \mathrm{~mm}$ high. Pseudoparaphyses septate, hyaline, branched above the asci, 1-1.5 $\mu \mathrm{m}$ wide. Asci bitunicate, cylindrical, short pedicillate, 8-spored, irregularly biseriate, 57.5-88 $\times 9-11 \mu \mathrm{m}$. Ascospores ellipsoid, slightly curved or straight, pale brown, concolorous, smooth, 3-septate, constricted at the septum, 14-16.5 × 4-6.5 $\mu \mathrm{m}$. Asexual state: Unknown.

Geographical distribution - Algeria, Argentina, Australia, Belgium, Bulgaria, Chile, Chinese Taipei, Denmark, France, Germany, Greece, India, Ireland, Luxembourg, Malay Peninsula, Morocco, Pakistan, Poland, Russia, Spain, Turkey, United Kingdom (Farr et al. 2013; GBIF 2013), Austria (Dämon et al. 2000), Italy, Japan, Norway, Portugal, Sweden, Ukraine, United States (as H. acuminatum, GBIF 2013), Libya (as H. angustatum var. cerotoniae, Farr et al. 2013), Mexico (Medel \& Guzman 1999) New Zealand, Kenya (Mugambi \& Huhndorf 2009), South Africa (Lee \& Crous 2003).

Material examined - Brazil, Paraíba, Areia, Mata do Pau-Ferro State Ecological Reserve, on twigs of unidentified plant, 7 Nov 2011, D.A.C. Almeida (HUEFS 131189); 4 Jul 2012, D.A.C. Almeida (HUEFS 192060).

Notes - Hysterium angustatum differs from $H$. pulicare Pers., the most similar species, mainly by concolorous and smaller ascospores. Recent phylogenetic analyses based on four nuclear genes demonstrated that they are closely related (Boehm et al. 2009b). Lohman (1933) and Zogg (1962) described larger asci $(105-120 \times 10-16 \mu \mathrm{m}$ and 100-120 $\times 11-14 \mu \mathrm{m}$, respectively) than found in the Brazilian specimens, while Ellis \& Everhart (1892) reported wider asci with similar lengths $(75-80 \times 12-15 \mu \mathrm{m})$. Ellis \& Everhart (1892) and Lohman (1933) described H. angustatum with larger ascospores $(15-22 \times 6-7 \mu \mathrm{m}$ and 22-26 $\times 6.5-8(9) \mu \mathrm{m}$, respectively) than observed in this study. The measurements of the asci and ascospores of the Brazilian material, however, are very similar to those stated by Lee \& Crous (2003). The hysterothecia described here have shallow slits, differing from the deep slits reported by the above authors. Although $H$. angustatum has a wide distribution, this is the first record for Brazil.

Hysterobrevium mori (Schwein.) E. Boehm \& C.L. Schoch, in Boehm, Mugambi, Miller, Huhndorf, Marincowitz, Spatafora \& Schoch, Stud. Mycol. 64: 62. 2009.

$\equiv$ Hysterium mori Schwein., Syn. Fung. Amer. bor.: no. 2087. 1832.

For more synonyms see Index Fungorum (www.indexfungorum.org).

Habitat - Saprobe on twig of unidentified plant. Sexual state: Hysterothecia superficial, carbonaceous, black, ellipsoid to elongate, with obtuse ends, straight or lightly flexuous, smooth or lightly striated laterally, with a longitudinal slit, sulcus shallow or deep, gregarious, linear, occurring on a black thin crust, without $\mathrm{KOH}$ extractable pigment, $0.3-1.7 \times 0.1-0.2 \mathrm{~mm}, 0.1-0.2$ $\mathrm{mm}$ high. Pseudoparaphyses septate, hyaline, branched apically above the asci, 1.5-2.5 $\mu \mathrm{m}$. Asci bitunicate, cylindrical, short pedicillate, 8-spored, irregularly biseriate, 65.5-95 × 12-16 $\mu \mathrm{m}$. Ascospores ellipsoid or clavate, straight, pigmented, smooth, with 4-5 transverse septa and one longitudinal septum usually associated with mid-cells and sometimes present obliquely in end cells, 15-20.5 × 6-7 $\mu \mathrm{m}$. Asexual state: Aposphaeria-like (Boehm et al. 2009a).

Geographical distribution - Germany (GBIF 2013), Argentina, Australia, Brazil, Canada, Costa Rica, Denmark, Ecuador, France, Ghana, India, Luxembourg, Norway, Pakistan, Portugal, Spain, Sweden, United Kingdom, United States (as Hysterographium mori, GBIF 2013), Austria (as Hysterographium pumilionis, GBIF 2013), Italy (as Hysterium grammodes, GBIF 2013), Malta (as Hysterium vulgare, GBIF 2013), Morocco (as Hysterographium grammodes, GBIF 2013), Venezuela (as Hysterographium punctiforme, GBIF 2013), Greece (Farr et al. 2013), Kenya (Boehm et al. 2009a), Tunisia (as Hysterographium ziziphi, Patouillard 1897). 


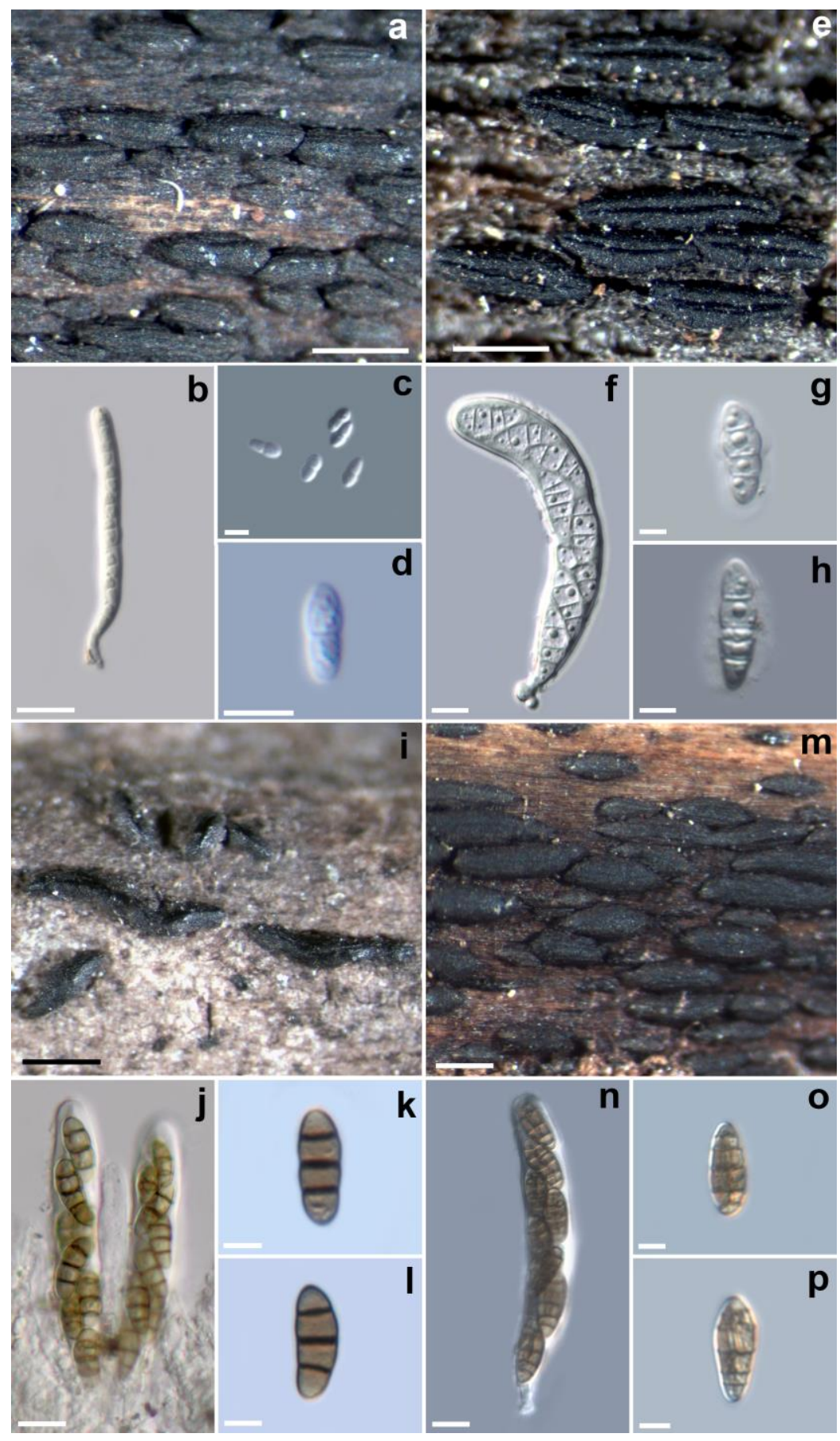

Fig. 1 - a-d Anteaglonium abbreviatum. a Hysterothecia. b Ascus with ascospores. c-d Ascospores. e-h Gloniella adianti. e Hysterothecia. f Ascus with ascospores. g-h Ascospores. i-l Hysterium angustatum. i Hysterothecia. j Asci with ascospores. k-1 Ascospores. m-p Hysterobrevium mori. $\mathrm{m}$ Hysterothecia. $\mathrm{n}$ Ascus with ascospores. o-p Ascospores. Bars $=0.5 \mathrm{~mm}(\mathrm{a}, \mathrm{e}, \mathrm{i}, \mathrm{m}), 10 \mu \mathrm{m}(\mathrm{b}, \mathrm{f}, \mathrm{j}, \mathrm{n}), 5 \mu \mathrm{m}(\mathrm{c}, \mathrm{d}, \mathrm{g}, \mathrm{h}, \mathrm{k}, \mathrm{l}, \mathrm{o}, \mathrm{p})$.

Material examined - Brazil, Piauí, Caracol, Serra das Confusões National Park, on twig of unidentified plant, 28 Mar 2011, D.A.C. Almeida (HUEFS 42835).

Notes - Hysterobrevium was recently erected by Boehm et al. (2009a) to accommodate three species transferred from other genera based on molecular analyses. Hysterobrevium mori (type species) was transferred from Hysterographium, while H. smilacis (Schwein.) E. Boehm \& C.L. Schoch and H. constrictum (N. Amano) E. Boehm \& C.L. Schoch were transferred from Gloniopsis. The measurements of the Brazilian specimen agree with Boehm et al. (2009a) and Ellis \& Everhart (1892), but some morphological variations were observed such as hysterothecia with obtuse rather than acuminate ends and ascospores that do not constrict at the median septum. 
Hysterobrevium smilacis (Schwein.) E. Boehm \& C.L. Schoch, in Boehm, Mugambi, Miller, Huhndorf, Marincowitz, Spatafora \& Schoch, Stud. Mycol. 64: 63. 2009.

$\equiv$ Hysterium smilacis Schwein., Schr. Naturf. Ges. Leipzig 1: 49. 1822.

Figs. 2a-d

For more synonyms see Index Fungorum (www.indexfungorum.org).

Habitat - Saprobe on twig of unidentified plant. Sexual state: Hysterothecia superficial, carbonaceous, black, navicular, straight or flexuous, smooth laterally, with a longitudinal slit, sulcus slightly deep, subgregarious to scattered, lying at irregular angles, without $\mathrm{KOH}$ extractable pigment, $0.3-1 \times 0.1-0.4 \mathrm{~mm}, 0.1-0.3 \mathrm{~mm}$ high. Pseudoparaphyses septate, hyaline, branched apically forming an epithecium above the asci, 1-1.5 $\mu \mathrm{m}$ wide. Asci bitunicate, cylindrical to clavate, short pedicillate, 8-spored, irregularly biseriate, 80-134 × 13-18 $\mu \mathrm{m}$. Ascospores ellipsoid, straight, hyaline, smooth, (4-)5-6 transversally septate, with a longitudinal septa usually associated with mid-cells and sometimes present obliquely in end cells, strongly constricted at the median septum, slightly constricted at other cells, surrounded by a gelatinous sheath, 16.5-24 × 6-9 $\mu \mathrm{m}$. Asexual state: Aposphaeria-like (Boehm et al. 2009a).

Geographical distribution - Australia, Austria, Belgium, Czech Republic, Estonia, France, Germany, India, Ireland, Italy, Morocco, Norway, Pakistan, Poland, Portugal, Russia, Spain, Sweden, United States (GBIF 2013), Ukraine (Farr et al. 2013).

Material examined - Brazil, Ceará, Ubajara, Ubajara National Park, on twig of unidentified plant, 4 May 2012, D.A.C. Almeida (HUEFS 155107).

Notes - The characteristics of the Brazilian specimen agree with the descriptions consulted (Ellis \& Everhart 1892; Boehm et al. 2009a). Although H. smilacis has a wide distribution, this study is the first to discover this species in Brazil.

Oedohysterium insidens (Schwein.) E. Boehm \& C.L. Schoch, in Boehm, Mugambi, Miller, Huhndorf, Marincowitz, Spatafora \& Schoch, Stud. Mycol. 64: 59 (2009)

$\equiv$ Hysterium insidens Schwein., Trans. Am. Phil. Soc., Ser. 2 4(2): 244. 1832.

Figs. 2e-h

For more synonyms see Index Fungorum (www.indexfungorum.org).

Habitat - Saprobe on twig of unidentified plant. Sexual state: Hysterothecia erumpent or superficial, carbonaceous, black, oblong, straight, smooth laterally, with a longitudinal slit, deep, gregarious, linear, occurring on a black thin crust, without $\mathrm{KOH}$ extractable pigment, $0.3-0.8 \times$ 0.1-0.3 mm, 0.1-0.3 mm high. Pseudoparaphyses septate, hyaline, branched above the asci, 1-1.5 $\mu \mathrm{m}$ wide. Asci bitunicate, cylindrical, short pedicillate, 8-spored, irregularly biseriate, $76-88 \times 16-$ $17 \mu \mathrm{m}$. Ascospores ellipsoid to fusiform, straight to slightly curved, brown, smooth, transversely $6-$ 8 -septate, constricted at septa, with a prominent swollen supra median cell, 25-35(-39) $\times 8-11 \mu \mathrm{m}$. Asexual state: Septonema spilomeum Berk. (Boehm et al. 2009a).

Geographical distribution - Australia, Canada, Germany, India, Italy, Portugal, Spain, South Africa, Switzerland, United Kingdom, United States (GBIF 2013), Brazil (as Hysterium apiculatum, GBIF 2013), Chile (as Hysterium batucense, Farr et al. 2013), Argentina (as Hysterium andicola, Spegazzini 1912), Morocco (as Hysterium atlantis, Maire \& Werner 1937).

Material examined - Brazil, Piauí, Caracol, Serra das Confusões National Park, on twig of unidentified plant, 28 Mar 2011, D.A.C. Almeida (HUEFS 42837).

Notes - Oedohysterium was erected by Boehm et al. (2009a) for three species based on molecular data. Oedohysterium insidens (type species) and O. sinense (Teng) E. Boehm \& C.L. Schoch were transferred from Hysterium, while O. pulchrum (Checa, Shoemaker \& Umaña) E. Boehm \& C.L. Schoch was moved from Hysterographium. The genus is characterized by phragmospores with a prominent swollen supra median cell. Oedohysterium insidens differs from $O$. sinense by smaller ascospores and from $O$. pulchrum by absence of longitudinal septa in the ascospores. The features of the Brazilian specimen agree with Boehm et al. (2009a) and van der Linde (1992), except the asci are shorter (130-150 $\mu \mathrm{m}$ versus 76-88 $\mu \mathrm{m})$ and there is a black thin crust under the ascomata. This black thin crust was observed by Schweinitz (1832) but not mentioned by Ellis \& Everhart (1892). The measurements are also similar to that reported by Ellis \& Everhart (1892), who examined the original type specimen, except the ascospores of the 
Brazilian specimen are wider $(6-8 \mu \mathrm{m}$ versus $8-11 \mu \mathrm{m})$.

Ostreichnion curtisii (Duby) M.E. Barr, Mycotaxon 3(1): 86. 1975.

Figs. 2i-1

$\equiv$ Hysterium curtisii Duby, Mém. Soc. Phys. Hist. nat. Genève 16(1): 42. 1861.

For more synonyms see Index Fungorum (www.indexfungorum.org).

Habitat - Saprobe on twigs or woods of unidentified plant. Sexual state: Hysterothecia superficial, carbonaceous, black, elongate conchate, straight, smooth laterally, with a longitudinal slit, sulcus deep, subgregarious to scattered, lying at irregular angles, without $\mathrm{KOH}$ extractable pigment. $0.3-0.7 \times 0.1-0.3 \mathrm{~mm}, 0.2-0.3 \mathrm{~mm}$ high. Pseudoparaphyses hyaline, septate, branched above the asci, 1-2.5 $\mu \mathrm{m}$ wide. Asci bitunicate, cylindrical, short pedicillate, 4-8-spored, irregularly biseriate, $128-133 \times 34-36 \mu \mathrm{m}$. Ascospores cylindrical, straight to slightly curved, subhyaline to pale brown, smooth, ends broadly rounded, 1-septate, septum submedian, strongly constricted at the septum, 59-62.5 × 14.5-17.5 $\mu \mathrm{m}$. Asexual state: Unknown. 2013).

Geographical distribution - Brazil (as Glonium curtisii, Zogg 1962), United States (GBIF

Material examined - Brazil, Paraíba, Areia, Mata do Pau-Ferro State Ecological Reserve, on twigs of unidentified plant, 3 Jul 2012, D.A.C. Almeida (HUEFS 192079); 18 Mar 2013, D.A.C. Almeida (HUEFS 192178); Bahia, Santa Teresina, Serra da Jibóia, on wood of unidentified plant, 9 May 2013, D.A.C. Almeida \& A.N. Miller (HUEFS 192249); Ceará, Ubajara, Ubajara National Park, on twigs of unidentified plant, 4 May 2012, D.A.C. Almeida (HUEFS 131816, HUEFS 131817); 6 May 2012, D.A.C. Almeida (HUEFS 155083); 14 Nov 2012, D.A.C. Almeida (HUEFS 192109).

Notes - Only three taxa are accepted in Ostreichnion: O. curtisii, O. nova-caesariense (Ellis) M.E. Barr and the type species, O. sassafras (Schwein.) M.E. Barr (Barr 1975; Boehm et al. 2009b). Ostreichnion curtisii is an atypical species in the genus and can be easily differentiated from the other two species by ascospores with a single septum. In a recent phylogenetic study based on molecular data of Hysteriaceae and Mytilinidiaceae, including $O$. sassafras and $O$. curtisii, Boehm et al. (2009b) found that Ostreichnion grouped inside Hysteriaceae and transferred it from Mytilinidiaceae. Another finding was that these two species are unrelated and the genus should be considered artificial.

The features of our material agree with Barr (1975) except the asci are shorter (128-133 $\mu \mathrm{m}$ versus 150-180(-220) $\mu \mathrm{m})$. Zogg (1962) reported on a specimen of $O$. curtisii from Brazil with smaller ascospores $((31-) 35-45(-53) \times(8-) 9-11(-13) \mu \mathrm{m})$, but considered it as a variation within the species.

Psiloglonium clavisporum (Seaver) E. Boehm, C.L. Schoch \& Spatafora, Mycol. Res. 113(4): 469. 2009.

Figs. 3a-d

$\equiv$ Glonium clavisporum Seaver, Mycologia 17(1): 4. 1925.

For more synonyms see Index Fungorum (www.indexfungorum.org).

Habitat - Saprobe on twig of unidentified plant. Sexual state: Hysterothecia superficial, carbonaceous, black, ellipsoid to elongate, straight or flexuous, smooth or striate laterally, with a longitudinal slit, sulcus deep, gregarious, linear, without $\mathrm{KOH}$ extractable pigment, $0.5-5 \times 0.1-0.4$ $\mathrm{mm}, 0.1-0.5 \mathrm{~mm}$ high. Pseudoparaphyses aseptate, hyaline, branched above the asci, 1-1.5 $\mu \mathrm{m}$ wide. Asci bitunicate, clavate, short pedicillate, 8-spored, obliquely uniseriate, 108.5-140 × 10-12 $\mu \mathrm{m}$. Ascospores clavate, straight or lightly curved, hyaline, smooth, 1-septate, constricted at the septum, 18-22.5 × 6-8.5 $\mu \mathrm{m}$. Asexual state: Sporidesmium stygium Berk. \& M.A. Curtis (Lohman 1937).

Geographical distribution - India (GBIF 2013), Japan (Hosoya \& Tanaka 2007), Nicaragua (as Glonium clavisporum, Seaver 1925), Saint Croix (as Glonium clavisporum, Seaver 1925), United States (Boehm et al. 2009b).

Material examined - Brazil, Paraíba, Areia, Mata do Pau-Ferro State Ecological Reserve, on twig of unidentified plant, 3 Apr 2013, D.A.C. Almeida (HUEFS 192176). 

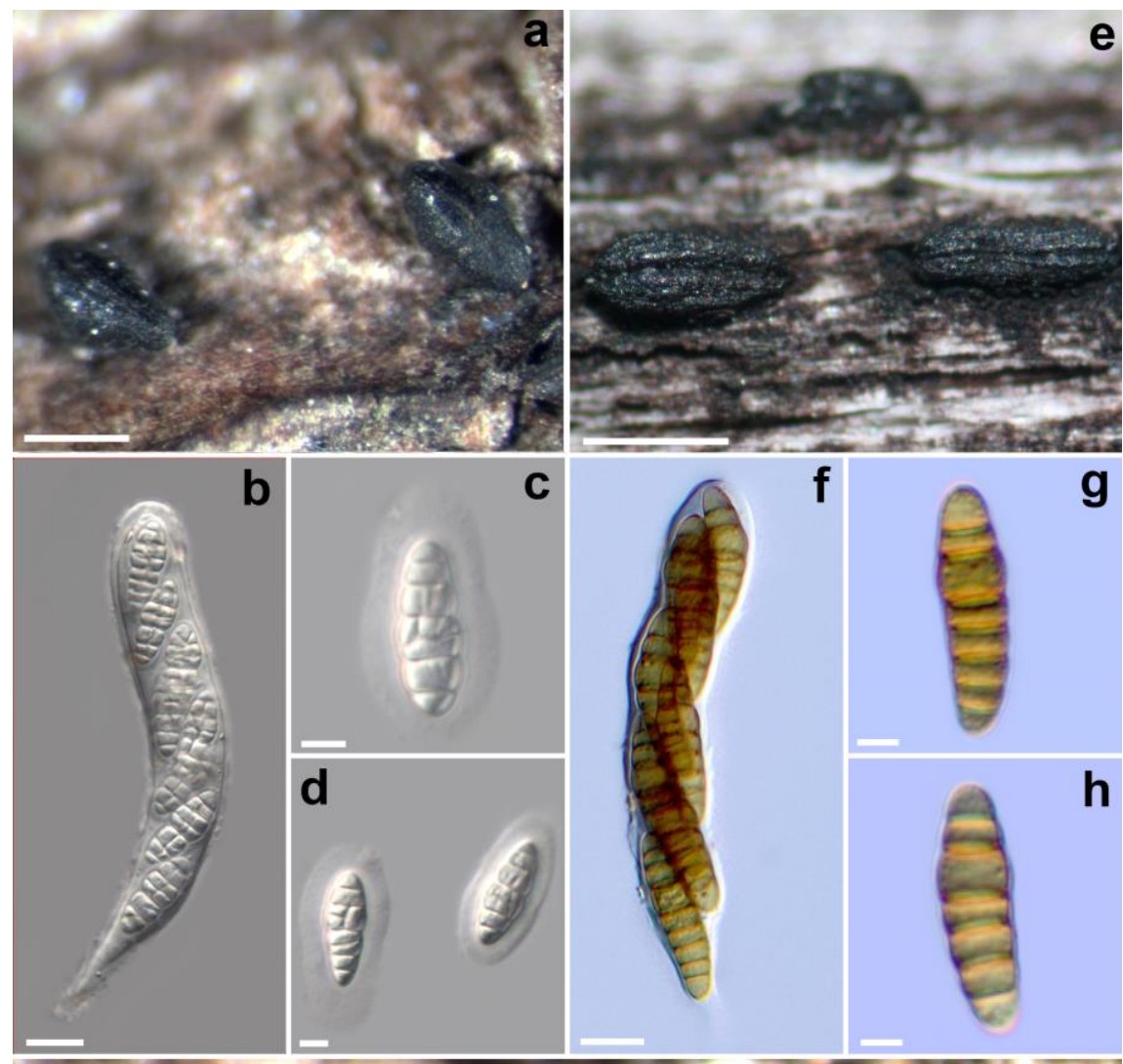

C
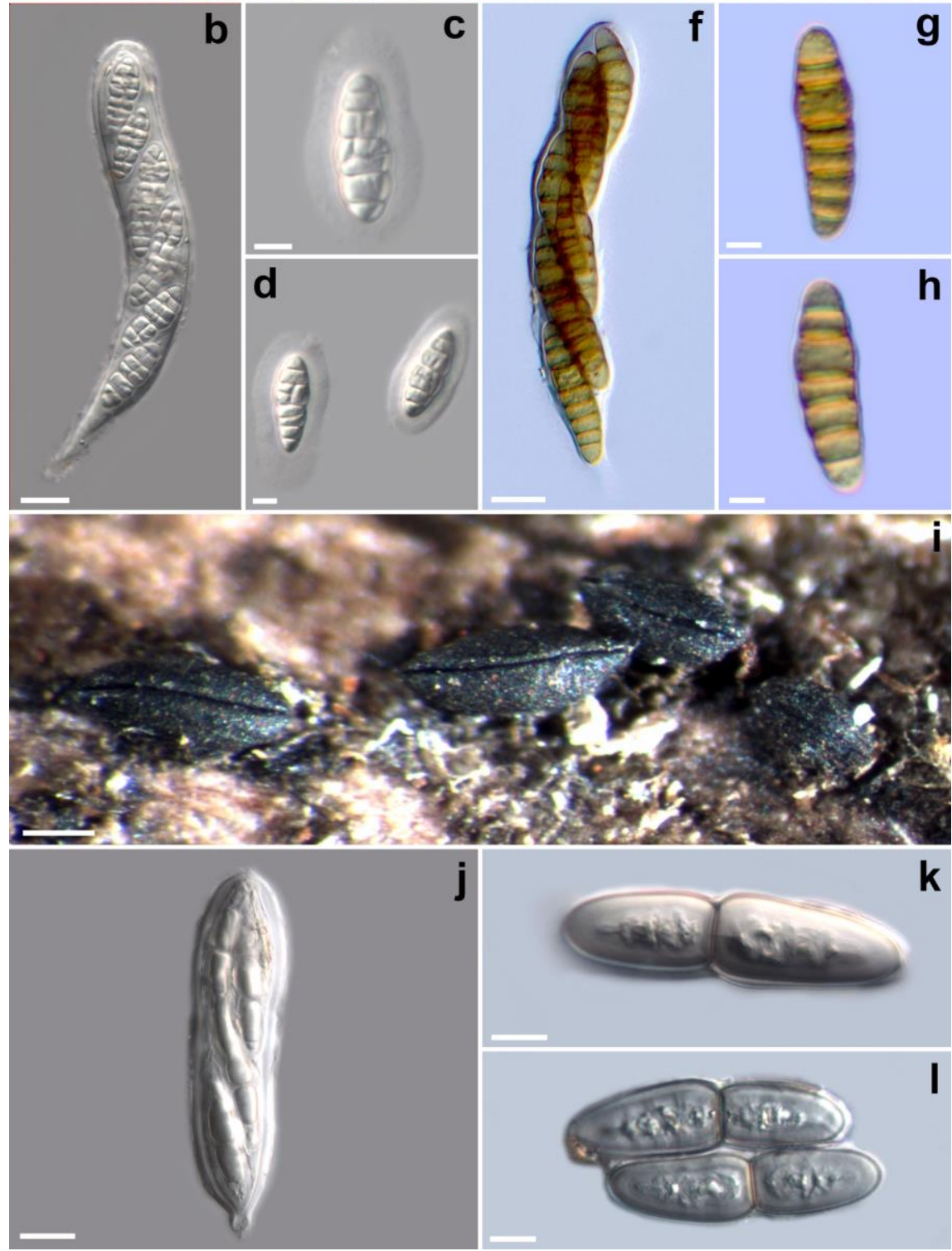

Fig. 2 - a-d Hysterobrevium smilacis. a Hysterothecia. b Ascus with ascospores. c-d Ascospores. e-h Oedohysterium insidens. e Hysterothecia. f Ascus with ascosopores. g- $\mathrm{h}$ Ascospores. i-1 Ostreichnion curtisii. i Hysterothecia. $\mathrm{j}$ Ascus with ascospores. $\mathrm{k}-1$ Ascospores. Bars $=0.5 \mathrm{~mm}$ (a, e), $0.2 \mathrm{~mm}$ (i), $20 \mu \mathrm{m}$ (j), $10 \mu \mathrm{m}(\mathrm{b}, \mathrm{f}, \mathrm{k}, \mathrm{l}), 5 \mu \mathrm{m}(\mathrm{c}, \mathrm{d}, \mathrm{g}, \mathrm{h})$.

Notes - Previously considered synonymous with Glonium by Zogg (1962), Psiloglonium was reinstated under Hysteriaceae by Boehm et al. (2009b) based on molecular data to accommodate species with unbranched, non-subiculate hysterothecia. Glonium was placed in its own family, Gloniaceae, closely related to Mytilinidiaceae, and retained species with dichotomously branched, laterally anastomosed, flabelliform or pseudo-stellate, subiculate hysterothecia. 
Due to the similarities between P. clavisporum and P. lineare (Fr.) Petr., Zogg (1962) considered them synonyms (under Glonium) despite the differences presented by Lohman (1937) such as ascospore length $((15-) 16-18(-22) \mu \mathrm{m}$ versus $(10-) 12-15 \mu \mathrm{m}$, respectively) and associated anamorph (Sporidesmium stygium versus pycnidial Plenomous, respectively). We agree with Lohman (1937) and Boehm et al. (2009b) that these differences are sufficient to maintain them as separate entities. Psiloglonium simulans (W.R. Gerard) E. Boehm, C.L. Schoch \& Spatafora was also considered by Zogg (1962) as a synonym (under Glonium) of P. clavisporum. Besides the morphological differences pointed out by Lohman (1937), Boehm et al. (2009b) provided additional evidence from molecular data for the separation of $P$. simulans and $P$. clavisporum.

The features of the Brazilian specimen agree with Seaver (1925) and Lohman (1937), except the asci are longer than those presented by Lohman (1937) $(90-110 \mu \mathrm{m})$. This study represents the first record of $P$. clavisporum for South America.

Rhytidhysteron opuntiae (J.G. Br.) M.E. Barr, Mem. N. Y. Bot. Gdn. 62: 72. 1990. Figs. 3e-h $\equiv$ Hysterographium opuntiae J.G. Br., Mycologia 45(6): 967. 1953.

For more synonyms see Index Fungorum (www.indexfungorum.org).

Habitat: Saprobe on twig of unidentified plant. Sexual state: Hysterothecia erumpent, carbonaceous, black, oblong, straight or flexuous, smooth laterally, with a longitudinal slit, sulcus deep, gregarious, lying at irregular angles, without $\mathrm{KOH}$ extractable pigment, $0.5-1.7 \times 0.2-0.5$ $\mathrm{mm}, 0.3-0.4 \mathrm{~mm}$ high. Pseudoparaphyses septate, hyaline, branched above the asci, 1.5-2.5 $\mu \mathrm{m}$ wide. Asci bitunicate, cylindrical to clavate, short pedicillate, 8-spored, uniseriate, 150-207 × 10$14 \mu \mathrm{m}$. Ascospores ellipsoid, ends obtuse, brown, smooth, transversally 3-septate, usually with one longitudinal septum in mid-cells, slightly constricted at median septa, thick-walled, 20-25 × 7.5-10 $\mu \mathrm{m}$. Asexual state: Unknown.

Geographical distribution - United States (as Hysterographium opuntiae, Brown 1953), Kenya (Boehm et al. 2009a).

Material examined - Brazil, Piauí, Caracol, Serra da Confusões National Park, on twig of unidentified plant, 28 Mar 2011, D.A.C. Almeida (HUEFS 42841).

Notes - Previously classified in the Patellariaceae (Samuels \& Müller 1979), Rhytidhysteron is now a member of the Hysteriaceae (Boehm et al. 2009a). The phylogenetic analyses carried out by Boehm et al. (2009a) indicate that the genus is artificial since the single isolate of $R$. opuntiae from Kenya grouped outside the clade formed by $R$. rufulum (type species) and $R$. hysterinum (Dufour) Samuels \& E. Müll. They preferred, however, to not remove $R$. opuntiae from Rhytidysteron until additional phylogenetic analyses with more isolates support this result.

The features of our material agree with Brown (1953) and Barr (1990b), except for the longer asci (85-160 $\mu \mathrm{m}$ and 130-160 $\mu \mathrm{m}$, respectively, vs. 150-207). This study is the first record of $R$. opuntiae for South America.

Rhytidhysteron rufulum (Spreng.) Speg., Anal. Soc. C ient. Argent. 90(1-6): 177. 1921.

$\equiv$ Hysterium rufulum Spreng., K. Svenska Vetensk-Akad. Handl. 46: 50. 1820.

Figs. 3i-m

For more synonyms see Index Fungorum (www.indexfungorum.org).

Habitat - Saprobe on twigs of unidentified plant. Sexual state: Hysterothecia erumpent, carbonaceous, black, navicular, straight or flexuous, striate laterally, striations perpendicular to the long axis, with a longitudinal slit, sulcus closed at first, then later opening to become irregularly apothecioid at maturity with incurved margins, gregarious, linear, without $\mathrm{KOH}$ extractable pigment, $0.8-2.5 \times 0.25-1.2 \mathrm{~mm}, 0.4-0.8 \mathrm{~mm}$ high. Pseudoparaphyses septate, hyaline, branched distally, 2-3 $\mu \mathrm{m}$ wide, covered by a black or red pseudoepithecium. Asci bitunicate, cylindrical to clavate, short pedicillate, 8-spored, irregularly uniseriate, 220-248 $\times 15-21 \mu \mathrm{m}$. Ascospores ellipsoid, ends rounded to subacute, straight or curved, central cells brown, concolorous or with median cells darker than distal cells, smooth, 3-septate, slightly constricted at the septa, thick walled, 21-32 $\times 7.5-11 \mu \mathrm{m}$. Asexual state: Diplodia-like and Aposphaeria-like (Samuels \& Müller 1979). 


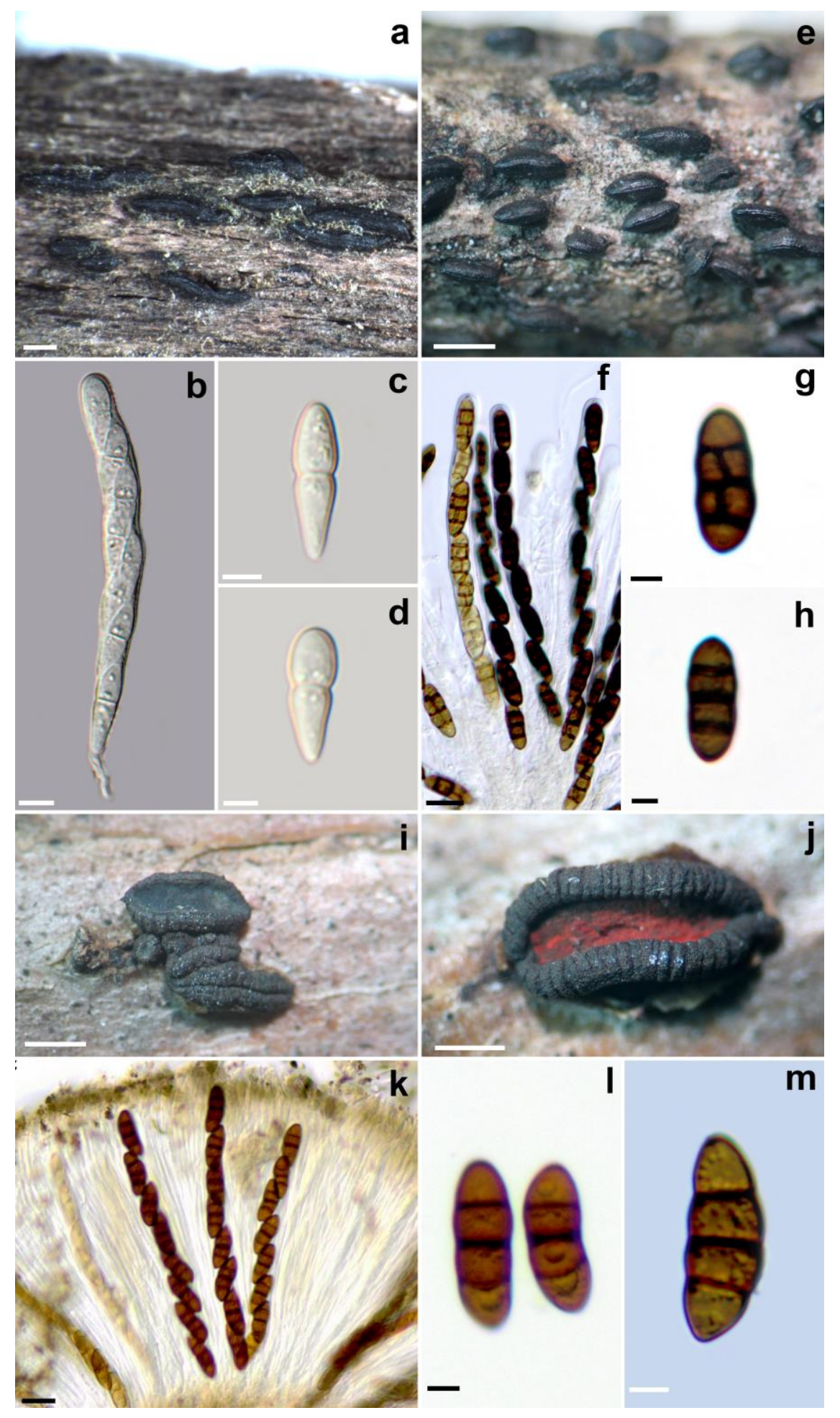

Fig. 3 - a-d. Psiloglonium clavisporum. a Hysterothecia. b Ascus with ascospores. $\mathrm{c}-\mathrm{d}$ Ascospores. e-h Rhytidhysteron opuntiae. e Hysterothecia. f Asci with ascospores. g-h Ascospores. i-m Rhytidhysteron rufulum. $\mathrm{I}-\mathrm{j}$ Hysterothecia. $\mathrm{k}$ Asci with ascospores and pseudoparaphyses. $1-\mathrm{m}$ Ascospores.

Bars $=1 \mathrm{~mm}(\mathrm{a}, \mathrm{e}, \mathrm{i}), 0.5 \mathrm{~mm}(\mathrm{k}), 20 \mu \mathrm{m}(\mathrm{f}, \mathrm{j}), 10 \mu \mathrm{m}$ (b), $5 \mu \mathrm{m}(\mathrm{c}, \mathrm{d}, \mathrm{g}, \mathrm{h}, 1, \mathrm{~m})$.

Geographical distribution - Argentina, Cook Islands, Costa Rica, Dominica, France, India, Japan, New Zealand, Philippines, Puerto Rico, Tonga, United States (GBIF 2013), China, Cuba, Ghana, Jamaica, Malaysia, Papua New Guinea, Sierra Leone, Tanzania (as Tryblidiella rufula, GBIF 2013), Brazil (Spegazzini 1881a), Micronesia (as Rhytidhysteron viride, GBIF 2013), Kenya (Boehm et al. 2009a). 
Material examined - Brazil, Piauí, Caracol, Serra das Confusões National Park, on twigs of unidentified plant, 28 Mar 2011, D.A.C. Almeida (HUEFS 42836, HUEFS 42845, HUEFS 131197, HUEFS 131198); 29 Mar 2011, D.A.C. Almeida (HUEFS 192084, HUEFS 192085); 30 Mar 2011, D.A.C. Almeida (HUEFS 192082); Paraíba, Areia, Mata do Pau-Ferro State Ecological Reserve, on twigs of unidentified plant, 8 Nov 2011, D.A.C. Almeida (HUEFS 131048, HUEFS 131049, HUEFS 192070); 3 Jul 2012, D.A.C. Almeida (HUEFS 192057); 17 Apr 2013, D.A.C. Almeida (HUEFS 192194); 18 Apr 2013, D.A.C. Almeida (HUEFS 192197, HUEFS 192199, HUEFS 192175); Ceará, Ubajara, Ubajara National Park, on twigs of unidentified plant, 4 May 2012, D.A.C. Almeida (HUEFS 131253); 16 Nov 2012, D.A.C. Almeida (HUEFS 192128); 19 May 2013, D.A.C. Almeida \& A.N. Miller (HUEFS 194207); Bahia, Santa Teresinha, Serra da Jibóia, on twig of unidentified plant, 10 May 2013, D.A.C. Almeida \& A.N. Miller (HUEFS 192253).

Notes - Murillo et al. (2009) performed an assessment of the intraspecific variability of $R$. rufulum among several isolates from Costa Rica based on molecular (ITS rDNA), morphological and chemical data. They found four distinct lineages that correlated with morphological differences (hysterothecia margin, pseudoepithecium color, asci and ascospores size) and chemical components. The authors, however, did not propose any nomenclatural changes, but highlighted the necessity of including isolates from other regions and a revaluation of the type specimens previously listed as synonyms of $R$. rufulum.

Our material agrees with the descriptions by Samuels \& Müller (1979), Kutorga \& Hawksworth (1997) and Murillo et al. (2009). The Brazilian specimen, however, has longer asci $(220-248$ vs. $77-100(-112) \mu \mathrm{m})$ and wider ascospores $((7.5-11$ vs. 3.5-4.5(-6.5) $\mu \mathrm{m})$ than reported by Samuels \& Müller (1979).

\section{Acknowledgements}

The authors thank the Brazilian Federal Agency for Support and Evaluation of Graduate Education (CAPES - proc. 071/2012), the National Council for Scientific and Technological Development (CNPq - proc. 14/2011), and the Program of Research on Biodiversity in the Brazilian Semi-arid (PPBIO Semi-arid/Ministry of Technology and Science - proc. 558317/20090 ) for financial support. The first author also thanks CAPES for the international scholarship to perform part of his doctoral research at the University of Illinois Urbana-Champaign (CAPES proc. 071/2012).

\section{References}

Barr ME. 1975 - The genus Ostreichnion. Mycotaxon 3 (1), 81-88.

Barr ME. 1990a - Melanommatales (Loculoascomycetes). North American Flora, Series II, Part $13,1-129$.

Barr ME. 1990b - Some Dictyosporous Genera and Species of Pleosporales in North America. Memoirs of The New York Botanical Garden 62, 1-92.

Barr ME. 2009 - A Nomenclator of Loculoascomycetous Fungi from the Pacific Northwest. North American Fungi 4, 1-94.

Batista AC, Bezerra JL, Castrillón AL. 1967 - Alguns Hysteriaceae de comum ocorrênca no Brasil. Atas do Instituto de Micologia 5, 191-200.

Bisby GR. 1923 - The literature on the classification of the Hysteriales. Transactions of the British Mycological Society 8 (3), 176-189. doi:http://dx.doi.org/10.1016/S0007-1536(23)80022-5

Boehm EW, Mugambi GK, Miller AN, Huhndorf SM, Marincowitz S, Spatafora JW, Schoch CL. 2009a - A molecular phylogenetic reappraisal of the Hysteriaceae, Mytilinidiaceae and Gloniaceae (Pleosporomycetidae, Dothideomycetes) with keys to world species. Studies in Mycology 64, 49-83. doi:10.3114/sim.2009.64.03

Boehm EW, Schoch CL, Spatafora JW. 2009b - On the evolution of the Hysteriaceae and Mytilinidiaceae (Pleosporomycetidae, Dothideomycetes, Ascomycota) using four nuclear 
genes. Mycological Research 113 (4), 461-479. doi:10.1016/j.mycres.2008.12.001

Brown JG. 1953 - A New Species of Hysterographium. Mycologia 45 (6), 964-967.

Checa J, Shoemaker RA, Umana L. 2007 - Some new hysteriaceous fungi from Costa Rica. Mycologia 99 (2), 285-290. doi:Doi 10.3852/Mycologia.99.2.285

Clements FE. 1909 - The genera of fungi. HW Wilson, Minneapolis, MN

Dämon VW, Forstinger H, Maurer W, Scheuer C, Abbildungen M. 2000 - Holzabbauende Pilze der Steiermark, III. Mitteilungen des Naturwissenschaftlichen Vereines für Steiermark 130, 43-70.

Ellis JB, Everhart BM. 1892 - The North American Pyrenomycetes. Newfield NJ. doi:http://dx.doi.org/10.5962/bhl.title.55690

Farr DF, Rossman AY, Palm ME, Mccray EB. 2013 - Fungal databases, systematic botany \& mycology laboratory, ARS, USDA. - http://nt.arsgrin.gov/fungaldatabases.

GBIF. 2013 - Global Biodiversity Information Facility Data Portal. - http://www.gbif.org.

Hosoya T, Tanaka K. 2007 - Ascomycetes and Anamorphic Fungi Collected from Yakushima Island, Southern Japan. Bulletin of the National Museum of Nature and Science 33, 47-54.

Hyde KD, Jones EBG, Liu J-K, Ariyawansa H, Boehm E, Boonmee S, Braun U, Chomnunti P, Crous PW, Dai D-Q, Diederich P, Dissanayake A, Doilom M, Doveri F, Hongsanan S, Jayawardena R, Lawrey JD, Li Y-M, Liu Y-X, Lücking R, Monkai J, Muggia L, Nelsen MP, Pang K-L, Phookamsak R, Senanayake IC, Shearer CA, Suetrong S, Tanaka K, Thambugala KM, Wijayawardene NN, Wikee S, Wu H-X, Zhang Y, Aguirre-Hudson B, Alias SA, Aptroot A, Bahkali AH, Bezerra JL, Bhat DJ, Camporesi E, Chukeatirote E, Gueidan C, Hawksworth DL, Hirayama K, Hoog S, Kang J-C, Knudsen K, Li W-J, Li XH, Liu Z-Y, Mapook A, McKenzie EHC, Miller AN, Mortimer PE, Phillips AJL, Raja HA, Scheuer C, Schumm F, Taylor JE, Tian Q, Tibpromma S, Wanasinghe DN, Wang Y, Xu JC, Yacharoen S, Yan J-Y, Zhang M. 2013 - Families of Dothideomycetes. Fungal Diversity 63 (1), 1-313. doi:10.1007/s13225-013-0263-4

Joshi GT, Patwardhan PG. 1971 - Gloniella (Hysteriaceae). A new generic record to India. Indian Phytopathology 24 (4), 787-788.

Kutorga E, Hawksworth DL. 1997 - A reassessment of the genera referred to the family Patellariaceae (Ascomycota). Systema Ascomycetum 15, 1-110.

Lee S, Crous PW. 2003 - Taxonomy and biodiversity of hysteriaceous ascomycetes in fynbos. South African Journal of Botany 69 (4), 480-488.

Lohman ML. 1933 - Hysteriaceae: Life histories of certain species. Papers of the Michigan Academy of Science Arts \& Letters 17, 229-288.

Lohman ML. 1937 - Studies in the Genus Glonium as Represented in the Southeast. Bulletin of the Torrey Botanical Club 64 (2), 57-73. doi:http://dx.doi.org/10.2307/2480907

Lorenzo LE, Messuti MI. 1998 - Noteworthy hysteriaceae from southern South America. Mycological Research 102 (9), 1101-1107. doi:10.1017/s0953756297006072

Lumbsch HT, Huhndorf SM. 2010 - Outline of Ascomycota-2009. Fieldiana Life and Earth Sciences 14 (1), 1-64. doi:http://dx.doi.org/10.3158/1557.1

Maire R, Werner RG. 1937 - Fungi maroccani. Catalogue raisonne des champignons connus jusqu'ici au Maroc. Mémoires de la Société des Sciences Naturelles du Maroc 45, 1-147.

Medel R, Guzman g. 1999 - Especies de macromicetos citadas de Mexico IX. Ascomycetes, Parte III: 1983-1996. Acta Botanica Mexicana 46, 57-72.

Messuti MI, Lorenzo LE. 2009 - Taxonomic studies on Gloniella (Hysteriales, Ascomycota) described by Spegazzini. Nova Hedwigia 89 (1), 229-236. doi:10.1127/00295035/2009/0089-0229

Mugambi GK, Huhndorf SM. 2009 - Parallel evolution of hysterothecial ascomata in ascolocularous fungi (Ascomycota, Fungi). Systematics and Biodiversity 7 (4), 453-464. doi:10.1017/s147720000999020x

Murillo C, Albertazzi FJ, Carranza J, Lumbsch HT, Tamayo G. 2009 - Molecular data indicate that Rhytidhysteron rufulum (ascomycetes, Patellariales) in Costa Rica consists of four distinct 
lineages corroborated by morphological and chemical characters. Mycological Research 113 (4), 405-416. doi:10.1016/j.mycres.2008.09.003

Pande A, Rao VG. 1991 - On three hysteriaceous fungi from peninsular India. Geobios new Reports 10, 62-64.

Patouillard NT. 1897 - Catalogue Raisonné des Plantes Cellulaires de la Tunisie, vol 7. Imprimerie Nationale,

Samuels GJ, Müller E. 1979 - Life-History Studies of Brazilian ascomycetes. 7. Rhytidhysteron rufulum and the genus Eutryblidiella. Sydowia 32, 277-292.

Schweinitz LDv. 1832 - Synopsis fungorum in America boreali media degentium. Transactions of the American Philosophical Society 4 (2), 141-316.

Seaver FJ. 1925 - The Fungous Flora of St. Croix. Mycologia 17 (1), 1-18. doi:http://dx.doi.org/10.2307/3753376

Sivanesan A, Rajak RC, Gupta RC. 1988 - New species of Gloniella from India. Transactions of the British Mycological Society 90 (4), 665-670. doi:http://dx.doi.org/10.1016/S00071536(88)80078-0

Spegazzini C. 1881a - Fungi argentini additis nonnullis brasiliensibus montevideensibusque. Pugillus quartus (Continuacion). Anales de la Sociedad Científica Argentina 12 (4), 174189.

Spegazzini C. 1881b - Fungi argentini additis nonnullis brasiliensibus montevideensibusque. Pugillus quartus (Continuacion). Anales de la Sociedad Científica Argentina 12 (5), 193 227.

Spegazzini C. 1912 - Anales del Museo Nacional de Historia Natural Buenos Aires. Mycetes argentinenses (Series VI) 23, 1-146.

Steinke TD, Hyde KD. 1997 - Gloniella clavatispora, sp. nov. from Avicennia marina in South Africa. Mycoscience 38, 7-9. doi:http://dx.doi.org/10.1007/BF02464962

van der Linde EJ. 1992 - Notes on the South African Hysteriaceae (Ascomyctes: Mycotina). South African Journal of Botany 58, 491-499.

Vitória NS. 2012 - Diversidade de Ascomycota em palmeiras nativas e exóticas em áreas de Mata Atlântica nos estados da Bahia e Pernambuco. PhD in Botany, Universidade Federal de Pernambuco, Recife, Pernambuco

Zogg H. 1962 - Die Hysteriaceae s. str. und Lophiaceae unter besonderer Berücksichtigung der mitteleuropäischen Formen. Beitrałge zur Krytogamenflora der Schweiz 11, 1-190. 